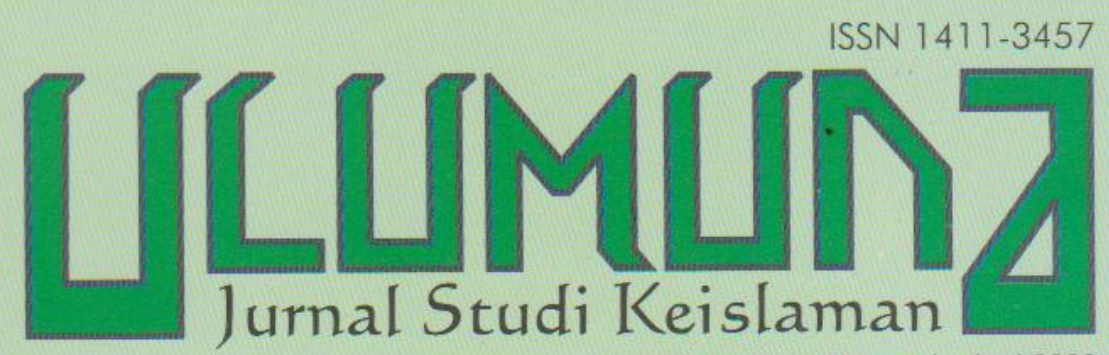

Volume XIII• Nomor $1 \cdot$ Juni 2009

TERAKREDITASI Berdasarkan SK Dirjen Dikti Depdiknas Nomor: 65a/DIKTV/Kep/2008

PEMIKIRAN FIQH DAN SPIRIT TRANSFORMASI SOSIAL Miftahul Huda

PERSPEKTIF MUHAMMAD SAT́D AL-ASYMÂWI TENTANG HISTORISITAS SYARI'AH Mutawalli

ASAS RETROAKTIF PADA KASUS PELANGgARAN HAM (PERSPEKTIF HUKUM ISLAM) Ikhwan

BMT DAN DEMOKRATISASI EKONOM: MEMBUMIKAN EKONOMI SYARIAH DI INDONESIA Lukman A - H Lkim

DINAMIKA PEMIKIRAN FIQH DALAM NU: ANALISIS ATAS NALAR FIQH POLA MAZHAB Ahmad Arifi

KOMPROMI DAN INTERSEKSIONALITAS GENDER DALAM PEMBERIAN MAHAR: TRADISI AMPA COI NDAI PADA SUKU MBOJO Atun Wardatun 


\section{PEDOMAN TRANSLITERASI}

\begin{tabular}{|c|c|c|c|}
\hline Arab & Latin & Arab & Latin \\
\hline 1 & $=$ & = & $=\mathrm{f}$ \\
\hline ب & $=$ & ق & $=\mathrm{q}$ \\
\hline$\dot{H}$ & ts & ك & $=\mathrm{k}$ \\
\hline 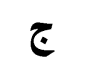 & $=$ & $J=$ & $=1$ \\
\hline$\tau$ & $=$ & b & $=\mathrm{m}$ \\
\hline$\dot{\tau}$ & $=\quad \mathbf{k h}$ & ن & $=\mathbf{n}$ \\
\hline$د$ & $=$ & و & $=\mathbf{w}$ \\
\hline$\dot{j}$ & $\mathrm{dz}$ & $\Delta$ & $=\mathbf{h}$ \\
\hline J & $=$ & $\varepsilon$ & $=$, \\
\hline j & $=$ & 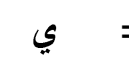 & $=\mathbf{y}$ \\
\hline س & $=$ & & \\
\hline ش ش & $\begin{array}{l}=\quad \text { sy } \\
=\quad \text { sh }\end{array}$ & \multicolumn{2}{|c|}{$\begin{array}{l}\text { Untuk Madd } \\
\text { dan Diftong }\end{array}$} \\
\hline ض & dl & $i$ & $=\hat{a}$ (a panjang) \\
\hline b & th & = & $=\hat{\mathbf{i}}(\mathbf{i}$ panjang $)$ \\
\hline ظ & $\mathbf{z h}$ & أو = & $=\hat{\mathbf{u}}$ (u panjang) \\
\hline$\varepsilon$ & $=$ & آو = & $=\mathbf{a w}$ \\
\hline$\dot{\varepsilon}$ & $=\mathbf{g h}$ & = آين & $=$ ay \\
\hline
\end{tabular}


TransLiterasi

ARTIKEL

Miftahul Huda

Mutawalli

Ikhwan

Kasjim Salenda

Hamid Fahmy

Rusli

Ahmad Arifi

Atun Wardatun
Pemikiran Fiqh

dan Spirit Transformasi Sosial $\bullet$ 1-22

Perspektif Muhammad Sa'îd al-Asymâwî

tentang Historisitas Syari'ah • 23-58

Asas Retroaktif

pada Kasus Pelanggaran HAM

(Perspektif Hukum Islam) • 59-80

Terorisme

dalam Perspektif Hukum Islam • 81-108

Genealogi

Liberalisasi Pemikiran Islam • 109-140

Kontroversi Akhbârî-Ushûlî

dalam Tradisi Pemikiran

Syı̀'ah Imâmiyyah • 141-168

Lukman Al-Hakim

BMT dan Demokratisasi Ekonomi:

Membumikan Ekonomi Syari'ah

di Indonesia • 169-188

Dinamika Pemikiran Fiqh dalam NU:

Analisis atas Nalar Fiqh

Pola Mazhab • 189-216.

Kompromi dan Interseksionalitas Gender dalam Pemberian Mahar: Tradisi Ampa

Co’i Ndai pada Suku Mbojo • 217-236.

\section{INDEKS}




\title{
KONTROVERSI AKHBÂRÎ-USHÛLÎ DALAM TRADISI PEMIKIRAN SYÎ'AH IMÂMIYYAH
}

\author{
Rusli* $^{*}$
}

\section{Abstract}

This paper deals with the controversy that occurs between Akbbârî and Ushâlî within Syî'ab Imâmiyyah's thought. The controversy lies on the legal methodology employed in understanding the will of God after the great occultation of the twelfth Imam. Akbbari, which is literalist in nature, tends to absolutely get rid of reason as a means of deriving Islamic laws, while insists on revelation and akhbâr of the Imams. They strictly hold that Shi'ites must absolutely follow such twelve imams, since it is only they who are able to accurately interpret the Quran. On the other hand, Ushûli allow the use of ijtihâd (legal reasoning) into a great deal in making legal decisions, and also argue that a Shi'ite must abide by mujtahid (legal experts), as well as the Imams. Therefore, they can come up with vital concepts in a religious life of Shi'ites nowadays, such as marja' al-taqlîd and wilâyat al-faqîh.

Keywords: Gerakan Sosial, Syî’ah Imâmiyyah, Akhbârî Ushûlî, Marja' al-Taqlîd, Wilâyat al-Faqîh.

WAFATNYA Nabi ternyata menciptakan satu kondisi yang memilukan dalam sejarah perpolitikan umat Islam. Siapa yang menggantikan Nabi dalam mengatur urusan umat yang baru tumbuh menjadi sebuah negara ini adalah satu pertanyaan yang menciptakan perpecahan dalam tubuh komunitas. Satu kelompok mengklaim bahwa hak tersebut berada pada pihak 'Alî bin Abî Thâlib dan keluarganya, dengan alasan adanya isyarat Nabi tentang masalah ini pada peristiwa Ghâdir Khum. Mereka ini kemudian disebut sebagai Syì'ah 'Alî. Kelompok lain, yang direpresentasikan oleh Sunnî, beranggapan tidak adanya

*Penulis adalah dosen Sekolah Tinggi Agama Islam Negeri (STAIN) Datokarama Palu, Sulawesi Tengah. email: rusli_mochtar@yahoo.com 
ketentuan dari Nabi, dan itu diserahkan kepada ijtihad umat. Dalam sejarah Sunnî, para khalifah seperti Abû Bakr, 'Umar, Utsmân, dan 'Alî yang dikenal sebagai al-Khulafâ' al-Râsyidûn adalah absah dan bahkan merupakan tipe ideal kepemimpian dalam sejarah politik kenegaraan Islam.

Dalam perkembangan selanjutnya, kelompok Syi'ah terpecah ke dalam beberapa sekte, di antaranya Zaydiyyah, ${ }^{1}$ Ismầîliyyah, ${ }^{2}$ dan Imâmiyyah. Namun, di antara sekte-sekte tersebut hanya

${ }^{1}$ Syî'ah ini dinisbatkan kepada Zayd bin 'Alî bin al-Husayn bin 'Alî bin Abî Thâlib, yang dianggap sebagai Imam ke-5 setelah wafatnya 'Alî Zayn al'Âbidîn (Imam ke-4). Aliran ini beranggapan bahwa imamah merupakan hak dari keturunan Fâthimah, dan tidak bisa dipegang oleh orang lain. Namun, mereka mengakui sebagai imam hanya dari keluarga Fâthimah yang terpelajar, saleh, berani dan dermawan, dan yang menyatakan kepemimpinannya: kesetiaan (baiat) mesti diberikan kepada salah seorang

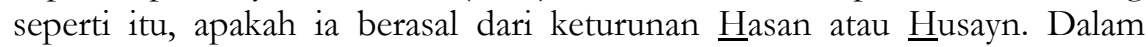
masalah-masalah teologis, Zayd bin 'Alî merupakan murid dari Wâshil bin 'Athâ'. Salah satu pandangan Zayd adalah bahwa seorang yang kurang utama (al-mafdlûh) memiliki kemungkinan untuk menjadi seorang imam meskipun ditemukan ada seorang yang lebih utama (al-afdlah). Pandangan lain darinya adalah bahwa seorang imam mesti melakukan pemberontakan agar bisa menjadi seorang imam. Pandangan-pandangan ini tidak ditentang oleh saudaranya sendiri, Muhammad al-Bâqir, yang dalam Syî'ah Imâmiyyah dianggap sebagai Imam ke-5. Ketika Zayd bin 'Alî dibunuh (oleh Hisyâm bin 'Abd al-Mâlik) dan dicabik-cabik tubuhnya di Kufah, Yahyầ bin Zayd menerima imamah itu, dan dibunuh di Juzyan Khurasan oleh Gubernurnya. Kemudian imamah beralih kepada Muhammad (dibunuh oleh 'Îsâ bin Hamân di Madinah) dan Ibrâhîm (dibunuh di Basrah), yang pembunuhan terhadap keduanya adalah atas perintah Manshûr. Lihat Muhammad ibn 'Abd al-Karîm al-Syahrastanî et.al, "Shi'ism, Zaydism, Isma'ilism, and Shaykhism" dalam Shi'ism: Doctrines, Thought and Spirituality, ed. Seyyed Hossein Nasr et.al. (Albany: State University of New York Press, 1988), 86.

${ }^{2}$ Syẩah Ismấn̂liyyah dinisbatkan kepada putra kedua dari Ja'far al-Shâdiq (Imam ke-6), Ismầîl, yang dikatakan bahwa ayahnya mengangkat dirinya menjadi imam sebagai pengganti dirinya. Namun, Ismấîl meninggal sebelum ayahnya. Jadi, dapat dikatakan bahwa sebenarnya Ja'far al-Shâdiq tidak digantikan olehnya. Setelah wafatnya Ja'far al-Shâdiq, imâmah yang pernah diberikan kepada Ismầil dengan penunjukan yang eksplisit, menurut sebuah kelompok, tidak jatuh kepada putra-putra Ja'far yang lainnya, tetapi kepada Muhammad bin Ismấîl. Lihat Paul E. Walker, "The Ismấîlî̀ Da"wa and the Fâtimid Caliphate", dalam The Cambridge History of Egypt, Vol 1: Islamic Egypt, 640-1517, ed. Carl F. Petry (Cambridge: Cambridge University Press, 1998), 121-2. 
sekte Imâmiyyah (Dua Belas Imam) yang lebih mendapatkan pengaruh yang luas dan masih tetap eksis di sebagian dunia muslim, terutama di Iran, yang menjadikan sekte ini sebagai mazhab resmi negara. Syîah Imâmiyyah (Dua Belas Imam) ini, menurut pengakuan Watt, ${ }^{3}$ mengambil bentuknya yang pasti antara tahun 874 dan 920 karena diasumsikan tidak mungkin ada bentuk Syı̀'ah ini, kecuali setelah wafatnya Imam ke-11 dan menghilangnya Imam ke-12.

Seperti di dunia Islam Sunnî, dalam Sŷ̀ah Imâmiyyah juga terdapat polarisasi dalam pemikiran hukum yang terbagi ke dalam dua kecenderungan metodologis: Akbbârî yang dikenal sebagai kelompok literalis-konservatif dan Ushûtî yang dikenal sebagai kelompok pengguna nalar dalam menciptakan produkproduk hukum. Apakah polarisasi itu terjadi karena semata-mata problem ideologis, atau perbedaan dalam pemahaman terhadap teks-teks hukum, atau karena alasan pragmatis-utilitarian? Untuk itu, pertanyaannya difokuskan pada hal-hal berikut ini: secara historis, kapan kedua trend pemikiran ini muncul? Apa yang menjadi faktor-faktor penyebab di balik kemunculannya itu? Aspek-aspek apa saja yang menjadikan kedua trend pemikiran ini menjadi berbeda? Di mana letak akar kontroversi antara kedua trend ini? Makalah ini mencoba menelusurinya dengan menggunakan logika dan pendekatan sejarah.

Sebelum menjawab pertanyaan-pertanyaan pokok tersebut, penulis terlebih dahulu mencoba menganalisis dan meletakkan kelompok Syî'ah dalam kerangka gerakan sosial (social movement), yang dalam diskursus ilmu sosial biasanya dibahas dalam dua paradigma. Paradigma pertama dikemukakan oleh Ralph Turner dan Lewis Killian, ${ }^{4}$ yang membagi gerakan sosial ke dalam tiga kategori. Kategori pertama adalah gerakan yang berorientasi nilai (value-oriented movement), yang dalam gerakan ini para anggotanya memiliki suatu komitmen terhadap prinsip menolak segala

${ }^{3}$ W. Montgomery Watt, "The Significance of the Early Stages of Imami Shi'ism", dalam Religion and Politics in Iran: Shi 'ism from Quietism to Revolution, ed. Nikki R. Keddie (New Haven \& London: Yale University Press, 1983), 21.

${ }^{4}$ Ralph Turner dan Lewis Killian, Collective Behaviour (Englewood Cliffs, New Jersey: Prentice Hall, 1957). 
bentuk kompromi demi suatu tujuan yang dicita-citakan. Kategori kedua adalah gerakan yang berorientasi kekuasaan (power-oriented movement), yang tujuan utamanya adalah perolehan kekuasaan, status dan pengakuan bagi para anggota dari gerakan tersebut. Satu dogma dari gerakan ini adalah asumsi bahwa hanya dengan menguasai kekuatan ekonomi dan politik, mereka dapat menghilangkan sesuatu yang mereka anggap sebagai kejahatan dalam masyarakat. Kategori ketiga adalah gerakan yang berorientasi pada partisipasi (participation-oriented movement) yang bisa mengambil bentuk, seperti gerakan reformasi pasif (passivereform movement) yang hanya menyuarakan adanya kekurangan dalam masyarakat, tetapi tidak berusaha secara aktif untuk menghilangkan kekurangan tersebut, atau dengan gerakan status personal (personal-status movement) yang menganjurkan pendefinisian kembali terhadap sistem status yang ada. Dengan pendefinisian itu diharapkan status mereka akan dapat terangkat.

Paradigma kedua dikemukakan oleh David Aberle dalam bukunya The Peyote Religion Among the Navaho (1966). Aberle membagi gerakan sosial ke dalam gerakan transformative, reformative, redemptive, dan alternative..$^{5}$ Gerakan pertama, transformative movement, adalah suatu gerakan yang bertujuan untuk melakukan perubahan secara total bagi individu atau masyarakat. Perubahan yang dikehendaki adalah perubahan yang menyeluruh, yang biasanya mencakup kekerasan dan perusakan. Reformative movement biasanya dilakukan untuk menghilangkan kekurangan-kekurangan dalam sebuah sistem sosial yang ada, tetapi tidak menghancurkan struktur mendasar dari sistem tersebut. Redemptive movement merupakan sebuah gerakan yang memusatkan pada perubahan individual ketimbang perubahan institusional. Terakhir, alternative movement berusaha menghilangkan tingkah laku individual secara parsial. Gerakan ini beranggapan bahwa manusia pada dasarnya adalah baik, tetapi bisa menjadi lebih baik melalui penghilangan karakter atau kebiasaan tertentu.

5Dikutip dalam Frank N. Magill, International Encyclopedia of Sociology, Vol. 2 (London, Chicago: Salem Press, 1995), 1244; Gordon Marshall, Oxford Dictionary of Sociology, Cet. ke-2 (Oxford, New York: Oxford University Press, 1998), 166. 
Muncul dan menguatnya sebuah gerakan sosial sangat bergantung pada faktor-faktor yang ada dalam dirinya sendiri (internal) dan juga di luar dirinya (eksternal), seperti kondisi sosial, budaya, dan politik. Namun, di antara faktor-faktor tersebut ada pula satu faktor yang perlu diberikan penekanan, yaitu figur kharismatik yang menjadi poros menguatnya sebuah gerakan atau mazhab. Kata "kharisma" didefinisikan Weber sebagai "kualitas tertentu seorang individu yang karenanya ia jauh berbeda dari orang-orang biasa dan dianggap memiliki kekuatan supranatural, manusia super, atau setidaknya luar biasa. Akan tetapi, semua itu dianggap berasal dan bersumber dari Tuhan, dan atas dasar itu, individu yang besangkutan diperlakukan sebagai pemimpin”. Kharisma dipandang Weber sebagai kekuatan inovatif dan revolutif, yang menentang dan mengacaukan tatanan normatif dan politik yang mapan. Otoritas kharismatis didasarkan pada person ketimbang hukum impersonal. Pemimpin kharismatik menuntut kepatuhan dari para pengikutnya atas dasar keunggulan personal, seperti misi ketuhanan, perbuatan-perbuatan heroik, dan anugerah yang membuat dirinya berbeda.

Institusionalisasi kharisma, dalam pandangan Weber, dapat diperoleh melalui beberapa cara, seperti melalui hubungan darah, keturunan, dan institusi. Jika dikaitkan dengan Syi`ah, adalah jelas bahwa kharisma merupakan bagian yang melekat dalam keyakinan mereka tentang imâmah 'Alî dan juga anak keturunannya (dua belas imam). Kharisma 'Alî dan para imam ini diperoleh tidak hanya dengan cara-cara seperti yang disebutkan di atas, tetapi juga melalui ilmu pengetahuan mereka yang mendalam dan sikap zuhud dan wara' mereka yang begitu tinggi. Pernyataan-pernyataan mereka dipercayai "benar" dan dipatuhi karena mereka dipercaya "dibimbing oleh Tuhan" dan terbebas dari dosa dan kesalahan (ma'shûm). Petunjuk ilahi tentang otoritas mereka, keturunan, kedalaman ilmu pengetahuan, dan kesalehan para imam menjadi dasar bagi "poros otoritas" (the axis of authority) yang kuat bagi mazhab Syî‘ah.

Wael B. Hallaq menegaskan bahwa menguat dan langgengnya empat mazhab fikih Sunnî tidak terlepas dari 
"poros otoritas" ini. Poros otoritas ini, menurut Hallaq, ${ }^{6}$ adalah tokoh yang dikenal sebagai pendiri, seorang faqîh terkemuka, yang dalam namanya prinsip-prinsip kumulatif dan kolektif dari mazhab itu ditawarkan. Pendiri mazhab ini disebut imam, yang menempa metodologi yang khas buat mazhabnya sendiri, dan tentu saja, pengetahuannya dalam semua bangunan ilmu keislaman harus menyeluruh. Kemudian, nama mazhab dinisbatkan kepada namanya. Dari fakta ini, pembangunan poros otoritas itu bukan hal yang mudah; banyak mazhab yang punah karena poros otoritasnya tidak begitu kuat.

Munculnya aliran Syî'ah dibangun dari sebuah konsep "poros otoritas" yang didukung dengan adanya "petunjuk Tuhan" kepadanya dan kharisma yang melekat pada dirinya. Keyakinan dan keterikatan kepadanya menjadi menguat sehingga perkataanperkataannya menjadi mengikat kepada umat. Mereka dianggap representasi dari Tuhan. Keyakinan ini menguat melalui proses, yang disebut oleh Antonio Gramsci, dengan "hegemoni". Hegemoni terjadi melalui indoktrinasi dan kemudian ini menguat dalam kesadaran sehingga apa yang telah dirumuskan menjadi diterima secara a priori.

Menurut Hallaq, poros otoritas mazhab bukan perkara mudah untuk dibangun. Ini menentukan suatu aliran bisa eksis atau menurun pengaruhnya, untuk tidak mengatakan punah. Semakin kuat poros otoritas dan upaya para murid dan pengikutnya untuk memperluas doktrin mazhab, maka penyebaran akan semakin kuat, selain tentunya dibantu oleh faktor politik. Menurut Hallaq, salah satu yang menentukan suatu aliran bisa bertahan atau menyebar secara meluas adalah ketika mazhab itu mampu melakukan "sintesis besar" (great synthesis) antara tradisionalisme dan rasionalisme, atau antara teks dan rasio. Kedua ranah ini memang dalam perjalanan sejarahnya seringkali mengalami konflik dan ketegangan seperti yang disinyalir oleh Coulson. ${ }^{7}$ Perjalanan hukum Islam itu sendiri merupakan perseteruan antara akal dan wahyu. Perseteruan ini

'Wael B. Hallaq, The Origins and Evolution of Islamic Law (Cambridge: Cambridge University Press, 2005), 157.

${ }^{7}$ Lihat Noel J. Coulson, Konflik dalam Yurisprudensi Islam, ter. Fuad (Yogyakarta: Navila, 2001), 4-24. 
bisa direfleksikan dalam perseteruan yang terjadi antara abl albadîts dan abl al-ra'y dalam sejarah ushôl al-fiqh Sunnî. Pada gilirannya, dari perseteruan ini akan muncul posisi menengah yang melakukan sintesis antara wahyu dan rasio, terutama dalam ushôl al-fiqh, seperti yang dimotori seorang ahli fiqh Syâfíiyyah, Ibn Surayj dari halaqah Baghdad.

\section{Syî‘ah Imâmiyyah: Kemunculan dan Perkembangan}

Seperti pernyataan Watt, Syî́ah Imâmiyyah (Dua Belas Imam) mengambil bentuknya yang pasti antara tahun 874 dan 920, karena menurut asumsinya, tidak mungkin ada sekte Syî'ah ini, kecuali setelah wafatnya Imam ke-11 dan menghilangnya Imam ke-12 (ghaybah). Dalam keyakinan mereka, Hasan bin 'Alî al'Askarî (Imam ke-11) mempunyai seorang anak bernama Muhammad yang bersembunyi dari kebencian dan permusuhan Khalifah al-Mu'tamid (w. 287/923). Setelah wafat ayahnya, Muhammad yang baru berusia lima tahun ini menjadi imam dan berkomunikasi dengan pengikutnya yang setia melalui serangkaian wakil/dutanya. ${ }^{8}$ Periode ini berlangsung selama 70 tahun dan dikenal sebagai "Kegaiban Kecil" (al-ghaybab alsughrâ..${ }^{9}$ Karya-karya Imâmiyyah awal menyebutkan tiga alasan di balik bersembunyinya Imam ke-12: 10

a. Al-Shâdiq diriwayatkan pernah mengatakan bahwa al-Qâim akan bersembunyi sebelum ia muncul lagi karena khawatir akan dibunuh.

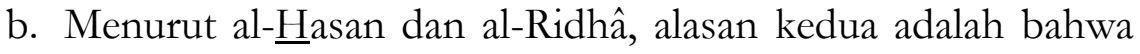
Imam ke-12 diriwayatkan telah menginformasikan kepada pengikutnya Ishâq bin Ya'qûb bahwa semua kakeknya telah memberikan baiat kepada para penguasa yang zalim, tetapi ia

'Yang menjadi duta imam (sufarâ') adalah (1) 'Utsmân bin Saî̀d al-'Umarî, (2) Abû Ja'far Muhammad bin 'Utsmân bin Saî̀d al-'Umarî, (3)

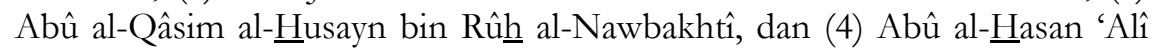
bin Muhammad al-Sammârî (duta terakhir).

${ }^{9}$ Abdullah Saeed, Islamic Thought: An Introduction (London \& New York: Routledge, 2006), 117-8.

10Dikutip dalam Jassim M. Hussain, The Occultation of The Twelfth Imam: Historical Background (USA: The Muhammadi Trust of Great Britain \& Northern Ireland, The Zahra Trust, 1982), Bab III. Download dari http:/ / www.al-islam.org/occultation_12imam.; diakses tanggal 23 Mei 2008. 
menyembunyikan dirinya agar bisa muncul melawan permusuhan tersebut, dan tidak menyatakan baiat kepada penguasa yang zalim itu.

c. Al-Kulaynî menyebutkan alasan ketiga bahwa ghaybah merupakan ujian yang dibuat Allah untuk makhluk-Nya agar bisa melihat siapa yang akan tetap loyal dan setia mengakui keimaman Imam ke-12.

Dengan kematian duta terakhirnya, Imam memasuki fase "Kegaiban Besar" (al-ghaybah al-kubrâ) pada tahun 329/939.11 Peristiwa ini kemudian menciptakan kevakuman yang serius dalam kepemimpinan Syî́ah Imâmiyyah. Situasi ini menyebabkan para fuqahâ' Imâmiyyah memperluas aktivitasaktivitas mereka. Mereka sepakat jika Imam ke-12 masih hidup dan akan muncul pada masa nantinya. Namun, dalam realitasnya mereka membutuhkan seorang pemimpin untuk menyelamatkan jemaat dari disintegrasi yang mungkin terjadi, dan tidak ada seorang pun yang mengambil tugas ini, kecuali diri mereka sendiri. Pada seperempat abad ke-4/10, orang-orang Syíah Imâmiyyah menerima pernyataan-pernyataan fuqahâ' sebagai pernyataan-pernyataan aktual dari Imam ke-12, tetapi tidak menganggap otoritas mereka sama dengan otoritasnya. Dengan kata lain, para fuqahâ' dianggap sebagai juru bicara para imam berkenaan dengan doktrin Islam dan hukum. Namun, mereka ini tidak memimpin jabatan imâmah karena, dalam asumsi mereka, tidaklah mungkin memegang jabatan imam sebelum munculnya Imam Mahdî. ${ }^{12}$

Karena alasan ini, para pemimpin Imâmiyyah terkemuka, seperti al-Mufîd dan al-Thûsî, menolak memberikan setengah dari bagian khums yang telah disediakan untuk imam kepada diri mereka sendiri. Al-Mufîd beranggapan bahwa pengikut setia yang ingin memberikan bagian imam seharusnya meninggalkannya untuk sementara waktu atau menyembunyikannya di tempat yang aman atau menguburkannya. Jika meninggal, ia harus mengalihkannya kepada orang terpercaya agar bisa diberikan kepada imam nantinya ketika ia muncul nanti. Setengah dari bagian khums

${ }^{11}$ Saeed, Islamic ..., 118.

${ }^{12}$ Hussain, Occultation ..., Bab VII. 
lainnya harus dibagi ke dalam tiga bagian dan diberikan secara sama kepada anggota keluarga Nabi yang membutuhkan, seperti anak-anak yatim, orang miskin, dan ibn al-sabil. ${ }^{13}$

Setelah masa Kegaiban Besar muncul dua orang fuqahâ' Syî'ah yang terkenal. Yang pertama adalah Ibn 'Aqîl al-'Umânî (ㅂasan bin 'Alî, pada paruh pertama abad ke-4), yang menyempurnakan fiqh Syíah, menggunakan sebagian pendapat yang baru, memisahkan bahasan-bahasan tentang ushôl dari furû́ dan mendasari metode-metodenya pada prinsip-prinsip ushûl alfiqh, yang ditolak oleh para fuqahâ' Imâmiyyah. Ia adalah orang pertama yang menggunakan ushîl al-fiqh dan melakukan penalaran intelektual. Setelah itu, Ibn Junayd al-Iskâfî (Abû 'Alî Muhammad bin Ahmad bin Junayd, w. 381/991) melanjutkan metode ini. Ia menulis beberapa buku, di antaranya Mukhtashar

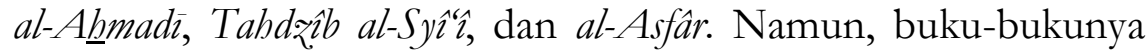
tersebut ditinggalkan banyak orang Syî'ah kala itu karena ia menggunakan qiyâs dalam penalarannya. ${ }^{14}$ Kedua tokoh ini disebut sebagai qadimayn pada abad ke-4/10.

Singkatnya, dalam perjalanan fiqh Syı̂‘ah Imâmiyyah, konflik dan ketegangan antara kecenderungan ijtihâd syar î dan ijtihâd 'aqlî terjadi, sebagaimana juga terjadi dalam tradisi pemikiran fiqh Sunnî. Bahasan berikut akan memfokuskan pada trend-trend tersebut yang, dalam tradisi pemikiran Syî́ah Imâmiyyah, terbagi ke dalam dua kecenderungan metodologis yang dominan, yaitu Akbbârî̀ dan Ushûlî.

\section{Akhbârî: Sejarah dan Epistemologi Hukum}

Akhbârî merupakan sebuah gerakan keagamaan dalam Syî́ah Imâmiyyah yang merupakan oposisi terhadap kelompok Ushûlî. ${ }^{15}$ Kata Akhbârî berasal dari kata khabar (plural: akbbâr) yang berarti riwayat/hadis para imam yang dianggap ma'shûm. ${ }^{16}$ Benih-benih

\section{${ }^{13}$ Ibid.}

${ }^{14}$ Mahmud Ramyar et.al, "Ijtihad and Marja'iyyat" dalam Shi ism ..., 230.

${ }^{15}$ Dikutip dalam "Twelvers/Ithna Ashari Islamic Schools of Thought". http:// www.globalsecurity.org/military/intro/islam-ithna-ashari2.htm; diakses tanggal 23 Mei 2008.

16Hamid Algar, "Akhbariyah" dalam Ensiklopedi Oxford Dunia Islam, Jilid I, ed. John L. Esposito (Bandung: Mizan, 2002), 85. 
kecenderungan akbbârî ini sebenarnya sudah ada pada masa Kegaiban Kecil, yang direpresentasikan para fuqahâ' Imâmiyyah seperti al-Kulaynî17 (w. 329/941) dan Ibn Bâbûya ${ }^{18}$ (w. 381/991). Kedua tokoh ini dikenal sebagai ulama Akbbârî klasik yang tidak kritis terhadap otoritas tradisi dalam ilmu agama. ${ }^{19}$

Meskipun benihnya sudah ada pada abad ke-4/10, gerakan Akbbârî mengkristal di bawah payung tulisan-tulisan Muhammad Amîn Astarabâdî (w. 1624), dan sangat berpengaruh pada abad ke-18, terutama pada masa-masa akhir dan pascaperiode Shafawi. Setelah jatuhnya dinasti Shafawi pada tahun 1722, aliran Akhbârî menjadi ortodoksi yang berkuasa. Tokoh berpengaruh dari aliran ini, Astarabâdî, dengan sengit menyerang aliran Syî́ah mujtabidî-ushûlî yang membolehkan penalaran hukum berdasarkan spesialisasi teknis, dan menuduh aliran ini sebagai bid'ah. Ia menolak ajaran sebagian besar faqîh setelah abad ke10, yang menegaskan bahwa prinsip-prinsip hukum yang mereka akui, seperti qiyâs, merupakan peminjaman dari yurisprudensi Sunnî. Namun, kemudian pengaruh Akbbârî bisa dihancurkan oleh para mujtahid Ushûlî pada akhir era dinasti Qajar.

Pada abad ke-11/17, tokoh Akhbârî yang terkemuka adalah Muhammad Taqiyy al-Majlisî (w. 1660) dan Mullah Muhsin Faydl Kâsyânî (w. 1680), yang keduanya memadukan kecenderungan sufi dengan tradisionalisme ketat dalam mazhab hukum mereka; al-Hurr al-'Âmilî (1624-1693) dan Sayyid Ni'mat al-Lâh al-Jazâ'irî. Pada abad ke-18, para ulama Akbbârî, khususnya di Bahrain, hampir sepenuhnya mendominasi 'Atabat, kota-kota suci Iran, yang merupakan pusat penting pengajaran Syî $a h$ setelah runtuhnya Dinasti Shafawiyyah (1501-1722). ${ }^{20}$

Dalam pandangan Akbbârî, yang menjadi sumber hukum adalah al-Qur'an, sunnah Nabi, dan akbbâr para imam. Nalar ('aq) tidak mendapatkan tempat dalam tradisi pemikiran

${ }^{17 D i}$ antara karya-karyanya adalah al-Ushûl min al-Kâfî̀ dan Furú 'al-Kâfî.

${ }^{18 D i}$ antara karya-karyanya adalah 'Tlal al-Syarâ'i', Ma'ânî al-Akbbâr, dan Man lâ Yabdlurubu al-Faqîh.

${ }^{19}$ Abdulaziz Abdulhussein Sachedina, The Just Ruler in Shi ite Islam: The Comprehensive Authority of the Jurist in Imamite Jurisprudence (New York, Oxford: Oxford University Press, 1988), 10.

${ }^{20}$ Algar, "Akhbariyyah..., 85. 
Akbbârî. Penggunaan nalar (ijtihad) dalam penerapan hukum kepada situasi yang khusus meskipun dalam masa kegaiban Imam ke-12 pun tidak diperbolehkan. Sebaliknya, aliran ini bersikukuh bahwa orang-orang Syî'ah harus taklid kepada 12 Imam karena hanya para imam yang ma'shûm saja yang dipercaya bisa memberikan tafsiran-tafsiran yang benar terhadap al-Qur'an itu sendiri. Mereka melarang taklid kepada siapa pun yang tidak ma'shûm, dan menegaskan bahwa semua orang Syî'ah mesti taklid kepada para imam. ${ }^{21}$ Ini mengandung pengertian bahwa mereka mendukung kemampuan semua orang beriman untuk menafsirkan tradisi-tradisi para imam. ${ }^{22}$

Dari fakta bahwa imam adalah penafsir al-Qur'an dan sunnah Nabi yang ma'shûm, menurut Astarâbâdî, akhbâr menjadi sumber terpenting yang tunggal, yang harus lebih didahulukan daripada makna lahiriyah al-Qur'an dan hadis Nabi. ${ }^{23}$ Dibolehkannya tindakan tertentu bergantung pada riwayat imam yang membolehkannya. Ketiadaan hadis menyebabkan tindakan tersebut meragukan dan lebih baik dihindari. Ketergantungan yang kuat terhadap akbbâr berakibat dibaginya semua hadis imam menjadi yang shahîh (kuat) dan yang dla ûf (lemah). ${ }^{24}$

Pandangan mereka tentang tidak bolehnya bersandar pada pemahaman akal dalam penetapan hukum syariat bisa ditafsirkan dalam tiga hal dengan ungkapan yang berbeda-beda:

a. mengingkari pemahaman akal terhadap baik dan buruk,

b. mengingkari keterlekatan antara akal dan hukum syariat, dan

c. mengingkari kewajiban mematuhi hukum syariat yang ditetapkan melalui akal; mengingkari otoritas akal. ${ }^{25}$

Mengapa mereka mengingkari akal sebagai penetap hukum atau menolak ijtihad? Jawabannya sederhana bahwa akal tidak membawa kepada pemahaman yang pasti tentang agama.

${ }^{21}$ Juan R. Cole, "Imami Jurisprudence and the Role of the Ulama: Mortaza Ansari on Emulating the Supreme Exemplar", dalam Religion..., 39.

22"Akhbārī". http://en.wikipedia.org/wiki/Akbbari; diakses tanggal 23 Mei 2008.

${ }^{23}$ Algar, "Akhbariyyah..., 85.

${ }^{24}$ Ibid.

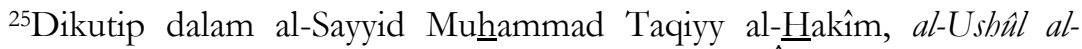
'Âmmah li al-Fiqh al-Muqâran, Tahqî̀: al-Majma' al-'Âlamî li Ahl al-Bayt (Qum: Mathba'ah Amîr, 1997), 284-5. 
Menurut mereka, ijtihad, yang mengantarkan kepada zhann (pendapat yang mungkin, sebagai lawan dari kepastian) dan taklid (mengikuti pendapat-pendapat seorang mujtahid) dilarang. Setiap mukmin mesti mengikuti akhbâr para imam karena pemahamannya yang tepat tidak hanya pengetahuan tentang bahasa Arab dan terminologi khusus dari para imam dibutuhkan. Jika konflik yang tampak antara dua tradisi tidak bisa dipecahkan oleh metode-metode yang telah diberikan para imam, tawaqquf (tidak memberikan satu putusan) adalah wajib. ${ }^{26}$

Dalam realitas sosial politik, kelompok Akbbârî ini tidak mengembangkan kontrol politik. Anggapan mereka adalah bahwa para ulama mesti memberikan nasehat kepada para pemimpin politik, tetapi bukan mengatur mereka. Pemahaman yang literalis dan konservatif dan penolakan terhadap peran akal dalam penetapan hukum membuat kaum Akbbârî menjadi kelompok minoritas yang ditinggalkan banyak orang. Kelompok ini pada masa sekarang bisa ditemukan di wilayah-wilayah seperti Irak, Iran, Bahrain, Pakistan, dan wilayah-wilayah non-Arab lainnya.

\section{Ushûlt̂. Sejarah Sosial dan Epistemologi Hukum}

Ushûlî merupakan sebuah gerakan keagamaan yang merupakan lawan Akbbârî.27 Kata "ushûlî" sendiri berakar dari istilah ushûl al-fiqh yang mempunyai kecenderungan dan wawasan yang lebih liberal daripada Akhbârî. Benih kecenderungan ushûlî awal dapat ditemukan pada abad ke-4/10 pada fuqahâ' seperti Ibn Junayd al-Iskâfî dan Ibn Abî 'Aqîl al-'Umânî. Kelompok Ushûlî membolehkan penggunaan ijtihad yang lebih luas dalam memproduksi putusan-putusan hukum dan beranggapan bahwa seorang mesti mematuhi mujtahid dan juga para imam. Pusat keagamaan Iran di Qum merupakan fokus Syî́ah Ushûlî. Dari tahun 1760-an aliran Ushûlî mulai menguasai pusat-pusat Syí‘ah

26Dikutip dalam Said Amir Arjomand, The Shadow of God and the Hidden Imam: Religion, Political Order, and Societal Change in Shi'ite Iran from the Beginning to 1890 (Chicago \& London: University of Chicago Press, 1984), 146.

27 "Twelvers/Ithna Ashari Islamic Schools of Thought," bttp:// www.globalsecurity.org/military/intro/islam-ithna-ashari2.htm; diakses tanggal 23 Mei 2008. 
yang strategis seperti Najaf dan Karbala di Irak. Dengan berdirinya dinasti Qajar pada tahun 1785, ulama Ushûlî muncul sebagai sebuah kekuatan yang diperhitungkan di seluruh Iran, dengan kepemimpinan yang memancar dari 'Atabat (Karbala dan Najaf di Irak).

Pada abad ke-11, kecenderungan Ushûlî diperkuat oleh tokoh-tokoh seperti Syarîf al-Murtadlâ (w. 1044) dan Abû Ja'far Muhammad bin Hasan al-Thûsî (w. 1067), yang berguru kepada seorang faqîh Imâmiyyah terkenal, Syaikh al-Mufîd (w. 1022). ${ }^{28}$ Syaikh al-Mufid ini merupakan seorang penyusun kitab ushûl alfiqh pertama dalam mazhab Syı̊‘ah, yaitu al-Tadzkirah fì Ushûl alFiqh. ${ }^{29}$ Namun, Syaikh al-Mufìd ini, seperti dikatakan Arjomand, ${ }^{30}$ menolak taklid, yang dalam pandangan Ushûlî malah diharuskan terutama bagi orang-orang awam. Namun, muridnya, Syarîf Murtadlâ yang menghancurkan pandangan tradisional itu dan menjustifikasi kebolehan dan perlunya taklid bagi orang-orang awam kepada mujtahid demi mencari nasehat. Alasannya, orang-orang awam tidak mempunyai pengetahuan yang dibutuhkan, bukan karena mujtahid mempunyai pengetahuan itu. ${ }^{31}$ Syarîf Murtadlâ ini juga mengembangkan disiplin ilmu ushâl al-fiqh setelah al-Mufid dan menulis kitab alDzarîah ilâ Ushûl al-Syarîah. ${ }^{32}$

Beberapa abad kemudian, pandangan Murtadhâ ini diikuti

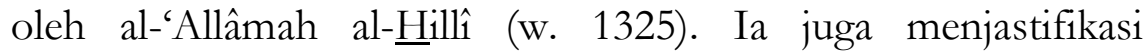
kebolehan taklid dengan pertimbangan praktis, yakni orang awam tidak mempunyai waktu yang diperlukan untuk memperoleh pengetahuan yang dibutuhkan demi menentukan perilaku yang benar secara etis dan ritual sehubungan dengan peristiwa-peristiwa baru. Ia menegaskan kembali kebolehan taklid dalam masalah-masalah furû́: Sebagaimana Murtadlâ,

28 Beberapa karyanya adalah Albkâm al-Nisâ', al-Masâil al-Marwiyyah, al-

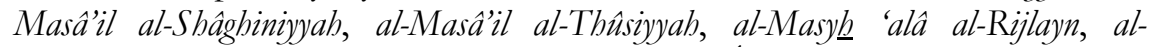
Muqni'ah, Jawâbât Abl al-Mûshil, Khulâshah al-îjâr, Drabâin̄ Abl al-Kitâb, Risâlah al-Mut'ah, dan Risâlah al-Mahr.

${ }^{29}$ Hasan $\underline{H}$ anafî, Min al-Nashsh ilâ al-Wâqi‘ (Kairo: Markaz al-Mathba'ah li al-Nasyr, 2004), 245.

30 Arjomand, Shadow ..., 139.

31 Ibid.

${ }^{32}$ Hanafî, Min ..., 245. 
'Allâmah lebih peduli pada penguatan kebolehan taklid daripada membuat penegasan yang empatik tentang kewajibannya sebagai kewajiban etis. 33

Meskipun diakui bahwa para fuqahâ' Syî́ah telah mempraktikkan ijtihad, penerimaan terhadapnya oleh Imâmiyyah datang kemudian, terutama ketika 'Allâmah alsecara eksplisit. Penerimaan ijtihad oleh 'Allâmah ini menjadi langkah yang sangat penting dalam meningkatkan otoritas hukum para ulama. Yang lebih penting lagi, ia menghubungkan ijtihad dengan kompetensi yang terkait dengan masalah-masalah dan bidang-bidang khusus, dan tidak membatasinya kepada ijtihad mutlak.

Langkah penting berikutnya adalah pada masa Shafawî, yang diambil oleh Ardabilî̀ (w. 1585) dan Al-Karakî (w. 1534). AlKarakî, misalnya, menentang kebolehan mengikuti mujtahid yang sudah meninggal. Dalam pemikiran ini tampak bahwa para teolog-fuqahâ' Syî́ah sedang berada dalam proses peletakan fondasi otoritas hirokratis (dewan ulama) dalam menghadapi tradisi Syî'ah yang berlawanan. Meskipun demikian, penghubungan yang tegas antara taklid dan ijtihad, dan munculnya gagasan ijtihad mutlak, yang menempatkan otoritas birokratis (dewan ulama) secara jelas dalam figur seorang mujtahid adalah penting dan menjadi indikasi bagi arah perkembangan berikutnya. Ardabilî bahkan memasukkan doktrin taklid dan ijtihad dalam kewajiban-kewajiban etis "al-amr bi al-ma'rûf wa al-naby an al-munkar". Dari sini, orang awam mesti berbuat menurut putusan seorang mujtahid ketika putusan itu telah dikeluarkan.

Kejayaan Ushâlî pada abad ke-18 dan ke-19 mulai memiliki signifikansi khusus, terutama ketika tokoh penting pendukung aliran Ushûlî, Muhammad Bâqir Bihbahânîi (1705-91), yang menetap di 'Atabat, kota suci Syi'ah di Irak, melawan dominasi Akbbârî yang kala itu mendominasi kota-kota suci di Irak. Ia dan para muridnya berhasil meyakinkan sebagian besar kolega mereka di Irak dan Iran untuk meninggalkan aliran Akhbârî. Setelah itu, kecenderungan metodologis Ushûlî mendominasi 
hampir seluruh wilayah yang bermazhab Syî́ah Imâmiyyah, bahkan hingga saat ini. Mengenai tokoh-tokoh penting yang mempunyai kecenderungan Ushûlî dari setelah masa Kegaiban Kecil hingga abad berikutnya, lihat pada bagan berikut.

\begin{tabular}{|c|c|c|c|}
\hline No. & Abad & Nama & Karya \\
\hline \multirow[t]{2}{*}{1} & $\mathrm{X}$ & 1. Ibn Junayd al-Iskâfî & 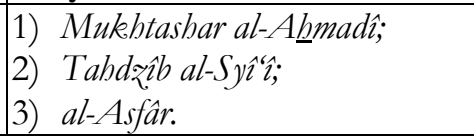 \\
\hline & & 2. Ibn 'Aqîl al-'Umânî & - \\
\hline \multirow[t]{2}{*}{2} & $\mathrm{XI}$ & 1. Syarîf al-Murtadlâ & $\begin{array}{l}\text { 1) al-Intishâr; } \\
\text { 2) Al-Nâsiriyyât; } \\
\text { 3) Rasâil al-Murtadlâa }\end{array}$ \\
\hline & & 2. Abû Ja 'far al-Thûsî & $\begin{array}{l}\text { 1) } \text { al-Iqtishâd; } \\
\text { 2) al-Khilâf; } \\
\text { 3) al-Rasầil al-'Asyr; } \\
\text { 4) al-Mabsûtb; } \\
\text { 5) al-Nihâyab; } \\
\text { 6) Mishbâh al-Muytabid. }\end{array}$ \\
\hline \multirow[t]{2}{*}{3} & XII & 1. Ibn al-Barrâj & $\begin{array}{l}\text { 1) Jawâhir al-Fiqb; } \\
\text { 2) al-Mûjaz; } \\
\text { 3) al-Kâmil. }\end{array}$ \\
\hline & & 2. Ibn Idrîs & 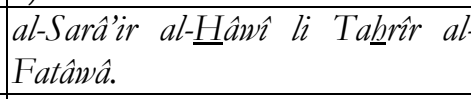 \\
\hline 4 & XIII & Muhaqqiq al-ㅂillî & $\begin{array}{l}\text { 1) Syarâ'i al-Islâm; } \\
\text { 2) al-Mukhtashar al-Nâfi: }\end{array}$ \\
\hline \multirow[t]{2}{*}{5} & XIV & 1. Al-'Allâmah al- $\underline{\text { Hillî }}$ & 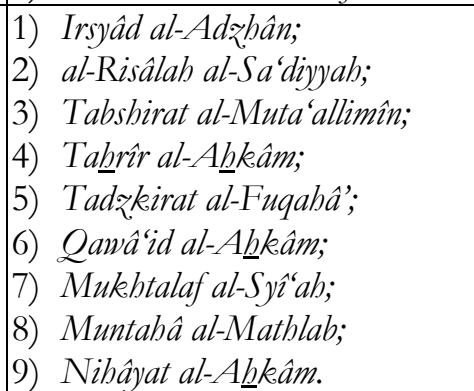 \\
\hline & & 2. Syahîd I & $\begin{array}{l}\text { 1) al-Alfiyyah wa al-Naqliyyah; } \\
\text { 2) al-Bayân; } \\
\text { 3) al-Durûs; } \\
\text { 4) al-Lum'ah al-Dimasyqiyyah; } \\
\text { 5) Dziker al-Syî"ah fì Alhkâm al } \\
\text { Syarî'ah. }\end{array}$ \\
\hline 6 & $\mathrm{XV}$ & Ibn Fahd al- $\underline{\text { Hillî̀ }}$ & $\begin{array}{l}\text { Al-Mubadzdzab al-Bâri' ilâ Syarb } \\
\text { al-Nâfi' }\end{array}$ \\
\hline 7 & XVI & Al-Muhaqqiq & Jâmi' al-Maqâshid fi Syarb al- \\
\hline
\end{tabular}




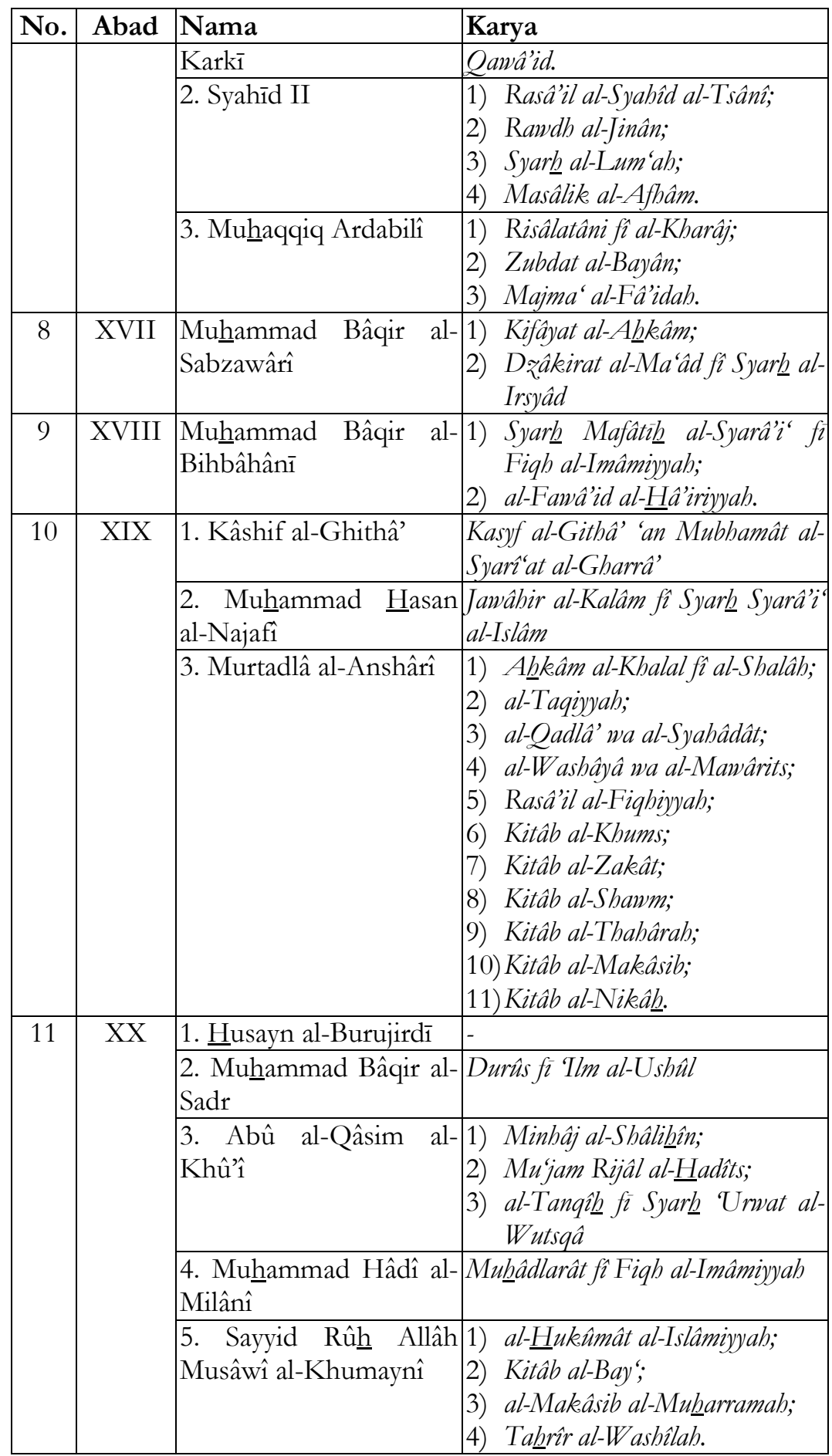

Sumber: Diramu dari berbagai sumber 


\section{Marja'al-Taqlîd}

Aliran Ushâlî_mengajarkan bahwa semua orang Syî‘ah terbagi ke dalam orang-orang awam dan pakar dalam ilmu agama. Kewajiban orang awam adalah mengikuti pakar ilmu agama (mujtahid). Teori ini menyediakan sebuah ideologi yang tentunya bisa digunakan untuk mendukung gagasan bahwa ulama seharusnya memainkan peran sebagai pembimbing masyarakat, meskipun gagasan bahwa ulama seharusnya yang memerintah tampak dianggap heretis (bid'ab) bagi sebagian besar mujtahid Syî'ah hingga saat ini. Taklid kepada mujtahid tidak hanya dianjurkan bagi orang-orang awam, tetapi juga, seperti ditegaskan Murtadlâ Anshârî, merupakan kewajiban yang absolut. ${ }^{34}$ Meskipun begitu, taklid hanya dibenarkan kepada mujtahid yang masih hidup dan paling terdidik. Taklid tidak diperkenankan kepada mujtahid yang sudah meninggal.

Dalam koridor Ushûlî, ini kemudian berkembang menjadi satu praktik terutama pada abad ke-19 yang mengakui seorang mujtahid sebagai sumber taklid (marja' taqlìd muthlaq). Lembaga ini memperkenalkan satu kemungkinan tentang kepemimpinan sentral yang kuat. ${ }^{35}$ Istilah marja' taqlìd menunjuk kepada otoritas tertinggi dalam komunitas Syî́ah Imâmiyyah. Jumlah mereka umumnya sangat sedikit. Otoritas yang terkait dengan marja taqlìd bergantung pada konvergensi historis dari dua struktur teoretis: ijtihad dan otoritas bukum. ${ }^{36}$ Mereka yang mempunyai kualifikasi untuk melakukan ijtihad harus berijtihad, sedangkan yang tidak mempunyai kualifikasi itu harus taklid kepada mujtahid. Para faqîh yang berkualitas dan lurus selama kegaiban imam telah diberikan otoritas bukum sebagai hâkim syarî̀ (hakim yang absah) dan nẩib al-imâm (wakil imam). Mereka juga sebagai pengelola yang lurus dalam hal zakat dan khums. Faqîh yang berperingkat tinggi mendapatkan bantuan finansial dari khums, yang menjamin independensi politis dan kekuasaan riil mereka.

${ }^{34}$ Dikutip dalam Juan R. Cole, Imami..., 44.

35 Ibid., 33-4.

36 Norman Calder, "Marja" Taqlid" dalam Ensiklopedi, Jilid 3, ed. Esposito, 342. 
Mereka yang pernah duduk sebagai marja' al-taqlìd adalah: Muhammad ㅌasan al-Najafî (w. 1850), Murtadlâ al-Anshârî (w. 1864), Muhammad Hasan bin Mahmûd al-Syîrâzî (w. 1895), Sayyid Abû al-Hasan al-Musâwî al-Isfahânî (w. 1945), Sayyid

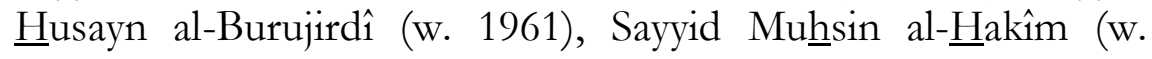
1970), Sayyid Muhammad Hâdî al-Milânî (w. 1975), Sayyid Muhammad Bâqir al-Shadr (dieksekusi 1980), Sayyid Abû alQâsim al-Khû'î, dan Sayyid Rûh al-Lâh Musâwî al-Khumaynî (w. 1989).

\section{Wilâyat al-Faqîh}

Konsep wilâyat al-faqîh (kepemimpinan seorang faqîh) menemukan momentumnya di dunia Syı̂‘ah ketika digunakan sebagai judul dari kuliah-kuliah yang disampaikan Ayatullah Khomeini (1902-1989) pada tahun 1969 kepada para mahasiswanya di Najaf. Ketika Khomeini menjadi hakim bagi semua masalah pemerintahan di Iran, maka menjadi jelas bagi dunia Islam bahwa kepemimpinan tersebut merupakan satu rute menuju sebuah pemerintahan ideal yang didengungkan oleh sebagian muslim kontemporer, yaitu pemerintahan Islam. Wilâyat al-faqîh ini didasari pada beberapa penjelasan Khomeini yang mendasar, sebagai berikut:

1. Seorang faqîh mempunyai "hak yang sama yang dimiliki oleh Nabi dan para Imam", meskipun ada fakta bahwa tidak ada seorang yang khusus diangkat oleh Tuhan untuk mengemban tugas pemerintahan pada masa Kegaiban Imam. Namun, Khomeini menolak pernyataan bahwa status faqîh itu identik dengan status para imam dan Nabi, dengan menegaskan bahwa wilâyat al-faqîh adalah masalah rasio dan eksternal yang disamakan dengan pengangkatan seorang wali kepada kelompok yang lebih kecil. Ia menegaskan bahwa seorang faqîh menikmati kekuasaan politik para imam.

2. Khomeini yakin bahwa wilâyah didukung oleh argumenargumen dari akal dan juga dari tradisi.

3. Khomeini mendefinisikan wilâyah sebagai sebuah institusi untuk memastikan penerapan yang ketat terhadap syariat kepada masyarakat muslim. 
4. Khomeini cenderung menggabungkan sejumlah argumenuntuk pendirian sebuah pemerintahan, tafsirannya terhadap kepemimpinan faqîh, dan revolusi politik terhadap penguasa yang menindas dan zalim-yang menyiratkan bahwa ia melihat adanya hubungan antara argumen-argumen itu yang memberikannya satu koherensi program. ${ }^{37}$

Latar belakang khusus dari teori ini sebenarnya ditemukan pada perkembangan-perkembangan dalam pemikiran Syî $a h$ Imâmiyyah abad ke-18 dan ke-19. Sekte Ushûlî memberikan hak ekslusif kepada mujtahid untuk menafsirkan hukum Islam. Jumlah mujtahid tidaklah banyak dan di antara mereka terdapat beberapa orang yang menerbitkan panduan-panduan yang menjelaskan praktik-praktik dasar bagi komunitas awam. Komunitas awam ini, menurut teori Ushâlî, diwajibkan untuk memilih salah satu dari mujtahid sebagai marja' al-taqlîd. Marja ini mendapatkan otoritas keduniawian dari Imam ke-12 dan mereka menerima donasi-donasi yang diberikan kepada imam yang tersembunyi. ${ }^{38}$ Otoritas itu memiliki implikasi politis.

Dari buku yang ditulis Khomeini tentang "pemerintahan Islam", ia berpendapat bahwa "umat Islam wajib membentuk pemerintahan tersebut dan para fuqahâ' berkewajiban menerima semua tugas yang pernah diemban Nabi Muhammad, termasuk pemerintahan." 39 Khomeini bahkan menyatakan kembali pandangan tradisional Syî́ah Imâmiyyah-Ushûlî bahwa setiap mujtahid (yang memiliki padanan yang sama dengan kata "faqîh" dalam konteks ini) mesti mengikuti pendapatnya sendiri. Ini menyiratkan bahwa tidak seorang mujtahid pun yang perlu menunda kepada yang lainnya dalam masalah-masalah pemerintahan. Seorang faqīh mempunyai pengetahuan dan integritas moral untuk mengemban tugas pemerintahan itu. Ia, kata Khomeini, "mempunyai otoritas yang sama dengan

37 Dikutip dalam Gregory Rose, "Velayat-e Faqih and the Recovery of Islamic Identity in the Thought of Ayatollah Khomeini" dalam Religion ..., 177-80.

38 Roy P. Mottahadeh, "Wilâyat al-Faqîh" dalam The Oxford Encyclopedia of the Modern Islamic World, Vol. 4, ed. John L. Esposito (New York, Oxford: Oxford University Press, 1995), 321.

${ }^{39}$ Dikutip dalam ibid. 
Rasulullah, dan merupakan kewajiban semua orang untuk mematuhinya." 40

\section{Kontroversi Akhbârî dan Ushûlî: Melacak Akar Masalah}

Memang ada beberapa titik persamaan antara Akbbârî dan Ushâlî, tetapi itu tidak begitu besar, di antara persamaannya adalah bahwa mereka mengakui al-Qur'an dan sunnah (yang mencakup perkataan dan perbuatan Nabi serta perkataanperkataan para imam) sebagai sumber hukum dan bahwa imâmah setelah wafatnya Nabi adalah jatuh di tangan 'Alî bin Abî Thâlib dan keturunannya hingga yang kedua belas. Jika dibuat perbandingan, perbedaan-perbedaan di antara mereka adalah cukup besar dan signifikan. Perbedaan-perbedaan tersebut mencakup perbedaan teologi dan epistemologi hukum. Untuk lebih jelasnya, bagan berikut memaparkan poin-poin perbedaan antara kedua aliran ini.

\begin{tabular}{|c|c|c|}
\hline No & Akhbârī & Ushûlî \\
\hline 1. & $\begin{array}{l}\text { Al-Qur;an dan hadis merupakan } \\
\text { satu-satunya sumber hukum Tuhan. }\end{array}$ & $\begin{array}{l}\text { Al-Qur'an dan hadis merupakan } \\
\text { sumber hukum, ditambah akal } \\
\text { dan ijmä. }\end{array}$ \\
\hline 2 & Ijtihad dalam agama dilarang. & $\begin{array}{l}\text { Ijtihad dalam agama adalah } \\
\text { sangat penting }\end{array}$ \\
\hline 3 & $\begin{array}{l}\text { Menggunakan ra'y dan qiyâs adalah } \\
\text { haram dan merupakan bid'ah. }\end{array}$ & Ra'y dan qiyâs digunakan. \\
\hline 4 & Taklid adalah wajib. & $\begin{array}{l}\text { Taklid dibolehkan hanya untuk } \\
\text { para pengikut, tetapi dilarang bagi } \\
\text { para mujtahid. }\end{array}$ \\
\hline 5 & $\begin{array}{l}\text { Taklid hanya kepada } 14 \text { imam yang } \\
\text { ma'shûm }\end{array}$ & $\begin{array}{l}\text { Hanya taklid kepada mujtahid } \\
\text { yang dibenarkan. }\end{array}$ \\
\hline 6 & $\begin{array}{l}\text { Otoritas tertinggi (ûlíal'amr) } \\
\text { hanyalah } 14 \text { orang, menggunakan } \\
\text { kata ini untuk yang lain adalah } \\
\text { diharamkan. }\end{array}$ & $\begin{array}{l}\text { Yang tidak ma'shûm sebagai } \\
\text { Penguasa Tertinggi (ûlî al-amr). }\end{array}$ \\
\hline 7 & $\begin{array}{l}\text { Menggunakan terma imam selain } \\
12 \text { Imam adalah dilarang. }\end{array}$ & $\begin{array}{l}\text { Yang tidak ma'shûm juga bisa } \\
\text { disebut imam. }\end{array}$ \\
\hline 8 & Wakil (Nấib) imam hanyalah imam. & $\begin{array}{l}\text { Yang tidak ma'shûm bisa menjadi } \\
\text { wakil imam }\end{array}$ \\
\hline 9 & $\begin{array}{l}\text { Hanya yang ma'shûm yang bisa } \\
\text { melakukan istinbâth hukum. }\end{array}$ & $\begin{array}{l}\text { Mujtahid mempunyai hak untuk } \\
\text { melakukan istinbâth hukum. }\end{array}$ \\
\hline
\end{tabular}

${ }^{40}$ Ibid. 


\begin{tabular}{|c|c|c|}
\hline No & Akhbârī & Ushûlî \\
\hline 10. & $\begin{array}{l}\text { Syahadat 'Alî waliy al-Lâh adalah } \\
\text { bagian yang integral yang tanpanya } \\
\text { kalimat tidak sempurna. }\end{array}$ & $\begin{array}{l}\text { 'Alî waliy al-Lâh bukan } \\
\text { merupakan bagian yang integral. }\end{array}$ \\
\hline 11. & $\begin{array}{l}\text { Nabi dan } 13 \text { Imam yang ma'shûm } \\
\text { adalah sama dalam semua dan } \\
\text { setiap aspek. }\end{array}$ & $\begin{array}{l}14 \text { yang ma'shûm itu tidaklah } \\
\text { sama. }\end{array}$ \\
\hline 12 & $\begin{array}{l}\text { Hak untuk menafsirkan al-Qur'an } \\
\text { hanya ada pada } 14 \text { yang ma'shûm } \\
\text { yang mempunyai pengetahuan yang } \\
\text { mendalam dalam ilmu pengetahuan } \\
\text { (al-râsikhûn fi al-'ilm) }\end{array}$ & $\begin{array}{l}\text { Mujtahid bisa menafsirkan al- } \\
\text { Qur'an melalui penalaran akal } \\
\text { (tafsîr bi al-ra'y). }\end{array}$ \\
\hline 13 & $\begin{array}{l}\text { Penghapusan dan pengubahan } \\
\text { dibuat dalam al-Qur'an. }\end{array}$ & $\begin{array}{l}\text { Tidak ada penghapusan dan } \\
\text { pengubahan yang dibuat dalam } \\
\text { al-Qur'an. }\end{array}$ \\
\hline 14 & $\begin{array}{l}\text { Memperoleh pengetahuan tentang } \\
\text { kesucian (ma'rifah nûrâniyyah) Nabi } \\
\text { Muhammad dan anak } \\
\text { keturunannya adalah wajib. }\end{array}$ & $\begin{array}{l}\text { Memperoleh pengetahuan } \\
\text { spiritual bukan merupakan } \\
\text { kewajiban dalam agama (taklif } \\
\text { syari), tetapi memahaminya hanya } \\
\text { sebagai makna verbal. }\end{array}$ \\
\hline 15 & $\begin{array}{l}\text { Mempraktikan pengetahuan } \\
\text { tentang ushûl al-fiqh adalah dilarang. }\end{array}$ & $\begin{array}{l}\text { Hanya mempraktikan } \\
\text { pengetahuan tentang ushôl al-fiqh } \\
\text { saja. }\end{array}$ \\
\hline 16 & $\begin{array}{l}\text { Pelukaan berdarah terhadap diri } \\
\text { sendiri (khooni matam) pada saat } \\
\text { meratapi Imam Husayn adalah } \\
\text { sesuai dengan hukum Islam. }\end{array}$ & $\begin{array}{l}\text { Pelukaan berdarah terhadap diri } \\
\text { sendiri (khooni matam) pada saat } \\
\text { meratapi Imam Husayn adalah } \\
\text { haram dan bid'ah dalam agama. }\end{array}$ \\
\hline 17 & $\begin{array}{l}\text { Keselamatan hanya dicapai melalui } \\
\text { kecintaan yang mendalam kepada } \\
\text { Alî dan melalui pengetahuan } \\
\text { tentang kesuciannya. (Amal } \\
\text { perbuatan sangat dituntut). }\end{array}$ & $\begin{array}{l}\text { Keselamatan hanya melalui amal- } \\
\text { amal yang nyata. (Mu'tazilah } \\
\text { mempercayai hal yang sama). }\end{array}$ \\
\hline 18 & $\begin{array}{l}\text { Menerima semua atribut Tuhan, } \\
\text { dan memohon belas kasih-Nya atas } \\
\text { segala dosa-dosa. }\end{array}$ & $\begin{array}{l}\text { Mengakui keadilan Tuhan } \\
\text { sehingga menolak belas kasih dari } \\
\text { Tuhan. (Mu'tazilah mempercayai } \\
\text { hal yang sama). }\end{array}$ \\
\hline 19 & $\begin{array}{l}\text { Amal-amal yang nyata merupakan } \\
\text { indikasi iman. }\end{array}$ & $\begin{array}{l}\text { Amal-amal yang nyata adalah } \\
\text { bagian iman yang integral. }\end{array}$ \\
\hline 20 & $\begin{array}{l}\text { Hadis hanya dikategorikan sebagai } \\
\text { benar dan salah }\end{array}$ & 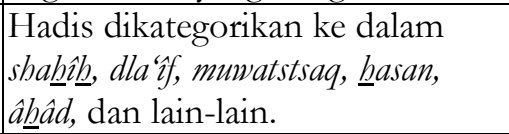 \\
\hline
\end{tabular}

Sumber: http://www.akhbari.org/differences.htm

Perdebatan yang paling asasi antara kedua kubu ini dalam pernyataan-pernyataan hukumnya berakar pada debat teologis 
tentang prioritas akal terhadap wahyu. Semenjak masa-masa awal sejarah Syî́ah Imâmiyyah, bahkan semenjak kepemimpinan alBâqir dan al-Shâdiq, ada diskusi di kalangan para sahabat dekat para imam tentang al-'aql (rasio), yang menyimbolkan otoritas dan bahkan prioritas penalaran manusia, dan al-atsâr atau alakbbâr, yang menyimbolkan otoritas wahyu. Pada masa keberadaan imam, putusan terakhir tentang masalah apa pun yang diperselisihkan berada di tangan para imam, yang tafsirantafsirannya terhadap al-Qur'an dan sunnah mengikat secara otoritatif karena keimanan dan ke- ma'shum-nya. ${ }^{41}$ Ijmâ' harus dilindungi dengan cara memasukkan pendapat imam yang ma'shûm ke dalamnya; jika tidak, ijmâ' tidak memiliki validitas hukum dalam pengeluaran produk hukum. Otoritas perkataan para imam, baik dalam hal akhbâr maupun ijmấ, adalah begitu penting dalam proses pembuatan hukum sehingga hanya ijtihad berbasis wahyu (al-ijtihâd al-syarî) saja dan bukan ijtihad berbasis akal (al-ijtihâd al-'aqlì) yang dianggap valid.

Kontroversi ini sebenarnya bisa dilacak kepada periode ketika para pendukung al-dalîl al-samî̀ (wahyu) mengusulkan dalil-dalil skriptural dan mencoba mendemonstrasikan bahwa akhbâr merupakan sumber yang memadai bagi kehidupan agama dan hukum umat Islam. Di sisi lain, para penganut al-dalîl al-'aqlî, yang juga disebut sebagai pendahulu ushûlî, menegaskan bahwa dalil rasional adalah sangat penting dalam menjelaskan prinsipprinsip keagamaan dan memperluas apa yang dianggap mengikat buat umat menurut ketentuan agama. Ini khususnya berlaku dalam masalah-masalah yang al-dalîl al-sam $\hat{\imath}$ tidak bisa memberikan informasi-informasi otentik yang penting untuk memasukkan akbbâr ke dalam praktik hukum. ${ }^{42}$

Al-Thûsî melakukan penelitian tentang akhbâr yang di dalamnya terjadi berbagai perbedaan dan pertentangan. Akibatnya, dalam karya fiqh terakhirnya, al-Mabsûth, ia menjelaskan metodenya, yaitu mengikuti ijtihad dan menyeimbangkannya dengan akbbâr untuk mengeluarkan putusan-putusan hukum. Alasan mengikuti metode ini, seperti yang dijelaskan dalam pendahuluan kitabnya itu, adalah bahwa

${ }^{41}$ Sachedina, Just ..., 19.

42 Ibid., 85. 
fuqahâ Imâmiyyah memasang tradisi-tradisi tanpa mentransmisikan ungkapan aktualnya sehingga putusan-putusan hukum yang didasari pada tradisi-tradisi tersebut gagal memasukkan pengertian terhadap kata-kata dari tradisi-tradisi itu. Lebih-lebih, fuqahâ' seringkali gagal memahami substansi dari tradisi-tradisi itu. Oleh karena itu, al-Thûsî memperbaiki situasi ini dengan menghadirkan 80 karya tentang fiqh dan menerapkan metodologi penyeimbangan antara ijtihad dan akbbâr. Semua karya al-Thûsî, baik tentang masalah fiqhh maupun ushâl al-dîn, mengindikasikan berbagai upayanya untuk melakukan kompromi yang menyenangkan, dengan menggabungkan dua bentuk argumentasi yang didasari pada al-sam' (wahyu) dan al-'aql (nalar). Dengan menerapkan metode ini, ia mampu membela ajaranajaran Imâmiyyah, mempelajari sejumlah besar tradisi, dan memberikan struktur teologis terhadap sebuah doktrin.

Kemampuan menggabungkan al-sam' dan al-'aql inilah yang menyebabkan sekte Ushûlî meraih kemenangan dalam perseteruan pemikiran antara kedua kubu ini. Ini terbukti bahwa sekte ini yang mendominasi wilayah-wilayah yang menganut mazhab Syì‘ah, terutama di Iran, dengan konsep khas Ushûlî-nya seperti marja' al-taqlîd dan wilâyat al-faqîh. Pada perkembangan berikutnya, berbagai kitab ushûl al-fiqh dalam kalangan Syîah lebih mencerminkan sintesis antara wahyu dan rasio ini. Di antaranya adalah kitab yang dikarang oleh ulama Syísah kontemporer terkenal, Muhammad Bâqir al-Shadr, Durûs fî̀ Tlm al-Ushûl. ${ }^{43}$ Dalam kitab itu, al-Shadr membagi dalil menjadi dua: dalîl syarî̀ lafîh $\imath^{44}$, yang mencakup bahasan tentang shîghat amr, naby, muthlaq, adawât al-umûm, adât al-syarth, dan seterusnya, dan dalîl 'aqlî. 45

Salah satu contoh perdebatan Akhbârî-Ushâlî adalah tentang kasus legalitas pernikahan seorang laki-laki dengan dua wanita yang merupakan keturunan puteri Nabi, Fâthimah. Dalam hal ini, penulis akan memaparkan perdebatan kasus tersebut dengan

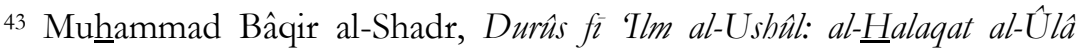
(Beirut: Dâr al-Kitâb al-Lubnânî, 1978).

44 Untuk lebih jelasnya lihat ibid., 84-143.

45 Untuk lebih jelasnya lihat ibid., 144-168. 
bersandar pada artikel yang ditulis oleh Robert Gleave. ${ }^{46}$ Dalam artikel tersebut, Gleave menjelaskan bahwa Akbârî berpandangan bahwa haram bagi seorang laki-laki menikahi dua wanita dari keturunan puteri Nabi, Fâthimah. Hal ini didasari pada sebuah khabar:

Saya mendengar Abû 'Abd al-Lâh [Imâm Ja'far al-Shâdiq] berkata, "Tidaklah halal bagi siapa pun untuk menikahi dua wanita dari keturunan Fâthimah, karena itu akan menyakiti hatinya dan membuatnya menderita." Aku bertanya, "Apakah itu benar-benar akan menyakitinya?" Ia menjawab, "Demi Tuhan, ya".

Khabar ini dijumpai pula dalam Kitâb al-Tlal karya al-Syaikh alShâdûq Ibn Bâbuyâ (atau Ibn Bâbawayh, w. 991), dengan isnâd: Ibn Bâbuya $\rightarrow$ Muhammad bin 'Alî $\rightarrow$ Muhammad bin Yahyâh $\rightarrow$ Ahmad bin Muhammad $\rightarrow$ Ayahnya Ahmad $\rightarrow$ Ibn Abî

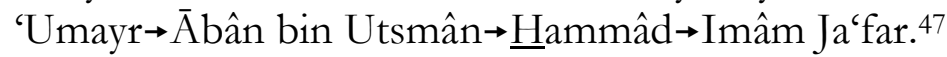

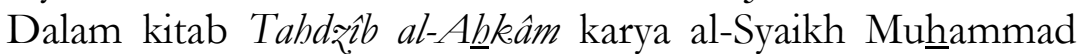
bin Hasan al-Thûsî (w. 1067), dengan isnâd yang berbeda: Shaykh al-Thûsî $\rightarrow$ 'Alî b. Hasan $\rightarrow$ al-Sindî b. al-Rabî̀ $\rightarrow$ Ibn Abî Amîr $\rightarrow$ salah seorang Syî'ah $\rightarrow$ Imâm Ja'far. ${ }^{48}$

Yûsûf al-Bahrânî (w. 1709), seorang tokoh Akbbârî yang terkenal, dalam bagian terakhir Risälah-nya, mendiskusikan status hukum dari perkawinan antara seorang laki-laki dengan dua wanita keturunan Fâthimah sebagai berikut.

Kami berpendapat bahwa menikahi dua wanita keturunan Fâthimah adalah haram; tidak ada keraguan atau ketidakpastian di seputar penjelasan [pandangan ini]. Persoalannya adalah apakah (1) larangan ini menjadikan perkawinan tersebut batal, atau (2) hanya dapat digambarkan sebagai dosa, dan perkawinan itu tetap sah. Jika yang pertama adalah kasusnya, apakah hukum yang menyatakan secara spesifik kontrak perkawinan dengan

46 Robert Gleave, "Marrying Fatimid Women: Legal Theory and Substantive Law in Shīî Jurisprudence", dalam Islamic Law and Society, 6, 1 (1999), 38-68.

47 Syaikh al-Shadûq Ibn Babuya, Tlal al-Syarâii (Najaf: al-Maktabah alHaydariyyah, 1383/1963), 590, no. 38.

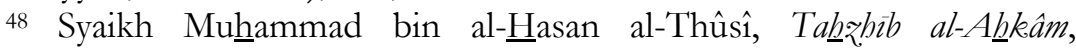
(Teheran: Dâr al-Kutub al-Islâmiyyah, 1390), vol. 7, 463, no. 1855. 
perempuan yang kedua itu tidak sah, atau seorang suami bisa memilih menceraikan isteri mana pun yang ia kehendaki? ${ }^{49}$ Jawaban dari al-Bahrânî ini adalah bahwa perceraian adalah pilihan yang diambil olehnya.

Kelompok Ushûlî menolak pandangan tentang keharaman pernikahan ini, seperti yang direpresentasikan oleh al-Bihbâhânî. Khabar ini dalam pandangannya adalah lemah dan perkawinan tersebut tidaklah dilarang dalam wahyu. Karenanya, ia mesti dianggap sebagai mubah. Al-Bihbâhânî ini tampak menggunakan logika istishbâh dan al-barâ'ah al-ashliyyah. Artinya, jika perkawinan bisa diterima oleh imam dan tidak ada aturan yang jelas bahwa itu dilarang (dan khabar ini, karena ia lemah, maka tidak menjadi aturan yang jelas), hukum mubah itu dianggap tetap berlangsung

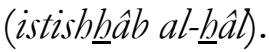

Dari dua perseteruan ini tampak terlihat adanya konflik dan ketegangan dalam pemahaman terhadap khabar dan penggunaan nalar terhadapnya. Satu kelompok menerima khabar sebagai suatu yang final dan harus dijalankan, sedangkan yang lain melihatnya lemah sehingga hukum awal tersebut terus

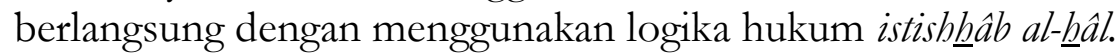

Contoh lainnya adalah perseteruan tentang persoalan politik dan otoritas hukum, yang mewujud dalam bentuk kepemimpinan para fuqahâ' (wilâyat al-faqîh) dan sumber rujukan bagi muqallid (marja' al-taqlîd) yang berlangsung hingga datangnya Imam Mahdî. Landasan konsep ini adalah pada kemaslahatan berbasis nalar, yakni umat Islam membutuhkan pemecahan terhadap persoalan-persoalan yang dihadapinya, dan tugas para fuqahâ, sebagai niyâbah Imam Mahdî, adalah membantu mencarikan solusi hukum terhadap hal itu. ${ }^{50}$ Bagi kelompok Ushûlî, persoalan ini jelas sangat signifikan seperti telah diuraikan pada bahasan sebelumnya. Namun, bagi kelompok Akbbârî, yang menolak otoritas akal dalam pembentukan hukum, isu-isu ini menjadi persoalan yang ditolak dengan serius karena tidak

${ }^{49}$ Dikutip dalam Gleave, Marrying ..., 50.

${ }^{50}$ Lihat Nâshir bin 'Abd al-Lâh bin 'Alî al-Qifârî, Ushûl Madz̧hab al-Syî̀'ah al-Imâmiyyah al-Itsnâ al-Asyariyyah: 'Ardl wa Naqd, Jilid 2 (tp: tt), 1165-1175; Rabî' bin Muhammad al-Su'ûdî, al-Syî̀ah al-Imâmiyyah al-Itsnâ al-Asyariyyah fî̀ Mî́ân al-Islâm (Kairo: Maktabah Ibn Taymiyyah, 1414 H), 205-8. 
ditemukan sandaran hukumnya dalam sunnah dan juga akbbâr para imam yang ma'shum, dan juga alasan bahwa para fuqahâ' bukanlah pengganti para imam yang suci, bahkan mereka tidak mempunyai peran dan andil dalam politik, seperti dibuktikan dalam kehidupan para imam yang ma'shum dan para pengikutnya. Untuk itu, mereka menolak kedua konsep itu, yang di dalam komunitas Iran saat ini menjadi ciri penting negara Islam Iran.

\section{Catatan Akhir}

Dalam kacamata ilmu sosial, Syî'ah merupakan sebuah gerakan yang bisa dimasukkan ke dalam paradigma gerakan sosial berorientasi nilai, kekuasaan, dan partisipasi. Kesemuanya dibangun pada prinsip "poros otoritas" [figur otoritatif] yang mempunyai kemuliaan, kesalehan, integritas, dan keilmuan. Mereka ini disebut sebagai "imam" yang dianggap ma'shum. Imam ini dibangun pada prinsip kharisma yang mengalami rutinisasi melalui keturunan, integritas, dan keilmuan. Kepatuhan terhadapnya menjadi mutlak karena, melalui proses doktrinisasi yang menguat melalui proses hegemoni, imam dianggap sebagai juru bicara Tuhan yang perkataan-perkataannya pasti benar karena mereka terlepas dari kesalahan (maksum).

Dalam perkembangannya, Syî́ah Imâmiyyah terpecah ke dalam sekte Akbbârî dan Ushûlî yang mempunyai kecenderungan metodologis yang berbeda. Titik tekan perbedaan tersebut terutama adalah pada peran akal dan wahyu dalam pengeluaran produk hukum. Namun, dalam perkembangannya, aliran yang mampu melakukan "sintesis besar" antara tradisionalisme dan rasionalisme sajalah yang akan terus bertahan dan menyebar. Ini terbukti dalam sejarah bahwa kelompok Ushûlî, yang melakukan "sintesis besar" itu, memenangkan perseteruan.

\section{Daftar Pustaka}

"Akhbârî". bttp://en.wikipedia.org/wiki/Akhbari. diakses tanggal 23 Mei 2008. 
"Basic differences between Shia Imamia Ithna Ashari Akhbari and Usooli," http://wnw.akhbari.org/differences.htm. diakses tanggal 23 Mei 2008.

“Twelvers/Ithna Ashari Islamic Schools of Thought". bttp:/ / www.globalsecurity.org/military/intro/islam-ithna-ashari2.htm.

diakses tanggal 23 MEi 2008.

Abdulaziz Abdulhussein Sachedina, The Just Ruler in Shi ite Islam: The Comprehensive Authority of the Jurist in Imamite Jurisprudence (New York, Oxford: Oxford University Press, 1988).

Abdullah Saeed, Islamic Thought: An Introduction (London, New York: Routledge, 2006).

Gordon Marshall, Oxford Dictionary of Sociology (Oxford, New York: Oxford University Press, 1998).

Gregory Rose, "Velayat-e Faqih and the Recovery of Islamic Identity in the Thought of Ayatollah Khomeini" dalam Religion and Politics in Iran: Shi ism from Quietism to Revolution, ed. Nikki R. Keddie (New Haven \& London: Yale University Press, 1983).

Hamid Algar, "Akhbariyah" dalam Ensiklopedi Oxford Dunia Islam, Jilid I, ed. John L. Esposito (Bandung: Mizan, 2002).

Hasan $\underline{H}$ anafî, Min al-Nashsh ilâ al-Wâqi (Kairo: Markaz alMathba'ah li al-Nasyr, 2004).

Jassim M. Hussain, The Occultation of The Twelfth Imam: Historical Background (USA: The Muhammadi Trust of Great Britain \& Northern Ireland, The Zahra Trust, 1982). http://wmw.alislam.org/occultation_12imam/; diakses tanggal 23 Mei 2008.

Juan R. Cole, "Imami Jurisprudence and the Role of the Ulama: Mortaza Ansari on Emulating the Supreme Exemplar", dalam Religion and Politics in Iran: Shiism from Quietism to Revolution, ed. Nikki R. Keddie (New Haven \& London: Yale University Press, 1983).

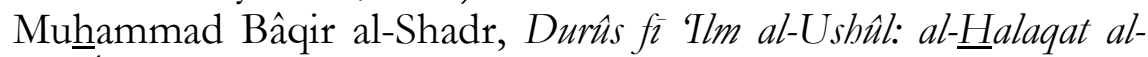
Ûlâ (Beirut: Dâr al-Kitâb al-Lubnânî, 1978).

Muhammad ibn "Abd al-Karim Shahrastani et.al, "Shi'ism, Zaydism, Isma'ilism, and Shaykhism" dalam Shi ism: Doctrines, Thought and Spirituality, ed. Seyyed Hossein Nasr et.al (Albany: State University of New York Press, 1988). 
Nâshir bin 'Abd al-Lâh bin 'Alî al-Qifârî, Ushûl Madð̧hab al-Syî'ah al-Imâmiyyah al-Itsnâ al-Asyariyyah: 'Ardl wa Naqd, Jilid 2 (tp: $\mathrm{tt})$.

Noel J. Coulson, Konflik dalam Yurisprudensi Islam, ter. Fuad (Yogyakarta: Navila, 2001).

Norman Calder, "Marja“ Taqlid" dalam Ensiklopedi Oxford Dunia Islam, Jilid I, ed. John L. Esposito (Bandung: Mizan, 2002).

Paul E. Walker, "The Ismâ'îlî Da'wa and the Fâtimid Caliphate", dalam The Cambridge History of Egypt, Vol 1: Islamic Egypt, 640-1517, ed. Carl F. Petry (Cambridge: Cambridge University Press, 1998).

Rabî' bin Muhammad al-Su'ûdî, al-Syîah al-Imâmiyyah al-Itsnâ alAsyariyyah fî Mî̀ân al-Islâm (Kairo: Maktabah Ibn Taymiyyah, $1414 \mathrm{H})$.

Ralph Turner dan Lewis Killian, Collective Behaviour (Englewood Cliffs, New Jersey: Prentice Hall, 1957).

Robert Gleave, "Marrying Fatimid Women: Legal Theory and Substantive Law in Shīi Jurisprudence", dalam Islamic Law and Society, 6, 1 (1999).

Roy P. Mottahadeh, "Wilâyat al-Faqîh" dalam The Oxford Encyclopedia of the Modern Islamic World, Vol. 4, ed. John L. Esposito (New York, Oxford: Oxford University Press, 1995).

Said Amir Arjomand, The Shadow of God and the Hidden Imam: Religion, Political Order, and Societal Change in Shi ite Iran from the Beginning to 1890 (Chicago \& London: University of Chicago Press, 1984).

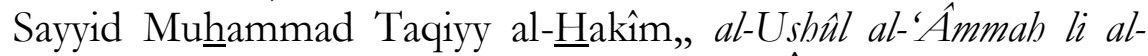
Fiqh al-Muqâran, Tahqî̀: al-Majma' al-'Âlamî li Ahl al-Bayt, (Qum: Mathba'ah Amîr, 1997).

Syaikh al-Shadûq Ibn Babuya, Tlal al-Syarâii (Najaf: al-Maktabah al-Haydariyyah, 1383/1963), 590, no. 38

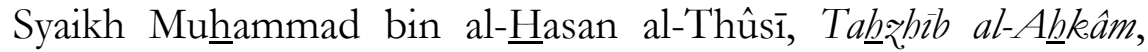
vol. 7 (Teheran: Dâr al-Kutub al-Islâmiyyah, 1390), 463, no. 1855.

W. Montgomery Watt, "The Significance of the Early Stages of Imami Shi'ism" dalam Religion and Politics in Iran: Shi ism from 
Quietism to Revolution, ed. Nikki R. Keddie (New Haven \& London: Yale University Press, 1983).

Wael B. Hallaq, The Origins and Evolution of Islamic Law (Cambridge: Cambridge University Press, 2005). 